\title{
Production of Multimeric Prostate-Specific Membrane Antigen Small-Molecule Radiotracers Using a Solid-Phase ${ }^{99 m}$ Tc Preloading Strategy
}

\author{
Preeti Misra ${ }^{1}$, Valerie Humblet ${ }^{1}$, Nadine Pannier $^{2}$, Wolfgang Maison ${ }^{2}$, and John V. Frangioni ${ }^{1,3}$ \\ ${ }^{I}$ Division of Hematology/Oncology, Beth Israel Deaconess Medical Center, Boston, Massachusetts; ${ }^{2}$ Institut fur Organische Chemie, \\ Universität Hamburg, Hamburg, Germany; and ${ }^{3}$ Department of Radiology, Beth Israel Deaconess Medical Center, Boston, Massachusetts
}

Small-molecule ligands specific for prostate-specific membrane antigen (PSMA) have the potential to improve prostate cancer imaging. However, highly charged ligands are difficult to label with $99 \mathrm{~m}$ Tc and to purify. In this study, we present an adamantanetrimerized small molecule that has nanomolar binding to PSMA and also has 12 negative charges. Methods: To convert this molecule into a clinically viable SPECT diagnostic, we have developed a simple, cartridge-based, solid-phase prelabeling strategy that, within $25 \mathrm{~min}$, converts readily available and inexpensive 99mTc-pertechnetate into a chemically pure complex, with a reactive $N$-hydroxysuccinimide (NHS) ester, in neat organic solvent. This stable intermediate can label any aminecontaining small molecule or peptide with ${ }^{99 \mathrm{mTc}}$ in 1 step, with high specific activity and without the need for high-performance liquid chromatography (HPLC). Results: Solid-phase conver-

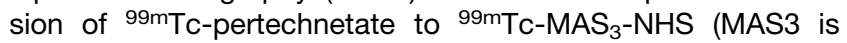
$S$-acetylmercaptoacetyltriserine) could be completed in $25 \mathrm{~min}$, with $>99 \%$ radiochemical purity and with no coligands present. This intermediate was then conjugated to adamantane-trimerized GPI (2[(3-amino-3-carboxypropyl)(hydroxy)(phosphinyl)methyl]pentane-1,5-dioic acid) in 1 step with $>95 \%$ yield and no need for HPLC purification. The final molecule bound specifically to living human tumor cells expressing PSMA on their surface. Quantitative comparison was made among GPI monomer, GPI trimer, and their 99mTc-derivatives. Conclusion: Our study describes a simple cartridge-based conversion of $99 \mathrm{mTc}-$ pertechnetate to a useful, preloaded NHS ester intermediate that takes only 25 min to prepare and results in $>99 \%$ radiochemical purity. Using this chemistry, we produced a highspecific-activity, ${ }^{99 m}$ Tc-labeled, PSMA-targeted small molecule and demonstrate $\gamma$-ray radioscintigraphic imaging of living human prostate cancer cells.

Key Words: 99mTc-pertechnetate; S-acetylmercaptoacetyltriserine $\left(\mathrm{MAS}_{3}\right)$; solid-phase chemistry; SPECT; prostate-specific membrane antigen

J Nucl Med 2007; 48:1379-1389

DOI: 10.2967/jnumed.107.040303

\footnotetext{
Received Jan. 31, 2007; revision accepted Apr. 23, 2007.

For correspondence or reprints contact: John V. Frangioni, MD, PhD, Division of Hematology/Oncology, Beth Israel Deaconess Medical Center, 330 Brookline Ave., Room SL-B05, Boston, MA 02215.

E-mail: jfrangio@bidmc.harvard.edu

COPYRIGHT @ 2007 by the Society of Nuclear Medicine, Inc.
}

$\mathbf{P}$ rostate cancer is diagnosed in approximately 230,000 men each year in the United States, and $>30,000$ of these will die of the disease (1). Every patient with biopsyconfirmed cancer requires clinical and radiographic staging to determine whether cancer has spread outside the capsule or has metastasized to regional lymph nodes or to bone. For patients already diagnosed with metastases, nuclear imaging could be used to pinpoint sites of disease and to quantify response to therapy.

SPECT is a nuclear medicine technique by which $\gamma$-ray emissions from a radioisotope are used to localize cancer and its products. The major radioisotope used clinically is ${ }^{99 \mathrm{~m}} \mathrm{Tc}$, which emits a monoenergetic, $140-\mathrm{keV}$ photon, has a 6-h half-life, and has a low absorbed dose. Most important, it is readily available at most institutions and is extremely inexpensive to produce, typically $\$ 10.00$ for $740 \mathrm{MBq}(20 \mathrm{mCi})$. The major problem with ${ }^{99 \mathrm{~m}} \mathrm{Tc}$ is that it is eluted using saline as sodium pertechnetate $\left(\mathrm{Na}^{99} \mathrm{mcO}_{4}\right)$ in the + VII oxidation state, which requires reduction to the $+\mathrm{V}$ oxidation state, as well as exchange chelation, for stability and subsequent chemical manipulation. Any chemistry capable of converting sodium pertechnetate to a more useful form would have immediate impact on diagnostic agent development.

Given its half-life, ${ }^{99 \mathrm{~m}} \mathrm{Tc}$ is an ideal radiotracer for any targeting molecule having a total-body clearance of $\leq 6 \mathrm{~h}$, such as small molecules, peptides, and single-chain antibodies. Of these, small molecules have distinct advantages for tumor targeting due to rapid biodistribution, rapid clearance, and excellent penetration into solid masses. Our group (2) and others $(3,4)$ have reported small molecules with highaffinity binding to prostate-specific membrane antigen (PSMA), a type II transmembrane glycoprotein expressed at high levels on normal and malignant prostate epithelial cells $(5,6)$. Our GPI (2[(3-amino-3-carboxypropyl)(hydroxy)(phosphinyl)methyl]pentane-1,5-dioic acid) molecule is a 311 -Da monomeric small molecule with an affinity of $9 \mathrm{nM}$ and a net charge of -4 after conjugation to contrast agents or radiotracers.

However, 2 major problems impede the use of GPI and similar molecules in diagnostic imaging. First, in its 
monomeric form, the phosphate anion in serum competes with it for binding to PSMA. Second, its chemical structure resembles classic exchange ligands, such as tartaric acid, which are required to stabilize ${ }^{99 \mathrm{~m}} \mathrm{Tc}$ during its reduction. Hence, ${ }^{99 \mathrm{~m}} \mathrm{Tc}$ could be chelated by GPI itself and block binding to PSMA, and HPLC purification of the final product using conventional labeling strategies is extremely difficult (7). In this study, we solve both problems by developing a simple and rapid cartridge-based, solid-phase prelabeling strategy for ${ }^{99 \mathrm{~m}} \mathrm{Tc}$ and also describe an adamantane-based trimeric form of GPI that retains full binding to living prostate cancer cells in the presence of serum.

\section{MATERIALS AND METHODS}

\section{Reagents}

MGI Pharma compound 11245-36 (GPI) was synthesized as described previously (8). Ultradry dimethyl sulfoxide (DMSO) was purchased from Acros Organics. HPLC-grade triethylammnonium acetate, pH 7 (TEAA), was from Glen Research. HPLC-grade water was from American Bioanalytic. Triserine was from Bachem. $N$-succinimidyl-S-acetylthioacetate (SATA) was from Pierce. $N, N$, $N^{\prime}, N^{\prime}$-Tetramethyl- $O$ - $(N$-succinimidyl)uronium tetrafluoroborate (TSTU) was from Advanced Chemtech. All other chemicals were purchased from Fisher Scientific and were American Chemical Society (ACS)- or HPLC-grade.

\section{HPLC/Mass Spectrometry Platform}

The HPLC/mass spectrometry platform used for purification of both nonradioactive and radioactive tumor-targeting small molecules and peptides has been described in detail previously (7). Briefly, the system is composed of a Waters model 1525 binary pump, a model 2487 ultraviolet detector (Waters), a Sedex model 75 (Richards Scientific) evaporative light scatter detector (ELSD) with the nebulizer modified to reduce band broadening at low flow rates, a model FC-3200 high-sensitivity photomultiplier tube $\gamma$-detector (Bioscan), and a Waters fraction collector, all housed within a Capintec hot cell equipped with a model CRC-15R (Capintec) dose calibrator. For nonradioactive reactions, column eluate was split into a Waters LCT electrospray time-of-flight (ESTOF) mass spectrometer.

\section{Preparative Synthesis of \\ S-Acetylmercaptoacetyltriserine $\left(\mathrm{MAS}_{3}\right)$}

Ten milligrams (36 $\mu \mathrm{mol})$ of triserine were dissolved in $350 \mu \mathrm{L}$ of water. One equivalent $(5 \mu \mathrm{L}, 36 \mu \mathrm{mol})$ of the base triethylamine $\left(\mathrm{Et}_{3} \mathrm{~N}\right)$ was added, followed by 2 equivalents $(16.6 \mathrm{mg}, 72$

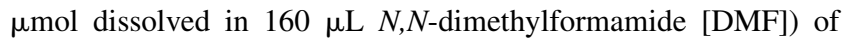
SATA. The reaction mixture was vortexed at room temperature for $3 \mathrm{~h}$. An additional equivalent $(8.3 \mathrm{mg}, 36 \mu \mathrm{mol}$ dissolved in $80 \mu \mathrm{L}$ DMF) of SATA was then added, and vortexing was continued for an additional $2 \mathrm{~h}$.

To confirm completion of the reaction, a $10-\mu \mathrm{L}$ sample was analyzed by reverse-phase HPLC (RP-HPLC) using a $4.6 \times 150 \mathrm{~mm}$ Symmetry (Waters) $\mathrm{C}_{18}$ column and a linear gradient from $0 \%$ to $15 \% \mathrm{~B}$ over $35 \mathrm{~min}$, starting $2 \mathrm{~min}$ after injection, at $1 \mathrm{~mL} / \mathrm{min}$, where $\mathrm{A}=\mathrm{H}_{2} \mathrm{O}+0.1 \%$ formic acid and $\mathrm{B}=$ acetonitrile $+0.1 \%$ formic acid. $\mathrm{MAS}_{3}$ eluted at a retention time $\left(\mathrm{R}_{\mathrm{t}}\right)=11.6 \mathrm{~min}$ as detected by the ELSD, with its mass confirmed by ES-TOF mass spectrometry. Preparative purification was performed on an HPLC system described in detail previously (7) and equipped with a 5-mL sample loop, after dilution into a final volume of $5 \mathrm{~mL}$ of $\mathrm{H}_{2} \mathrm{O}+$ $0.1 \%$ trifluoroacetic acid (TFA), and using a $19 \times 150 \mathrm{~mm}$ Symmetry $\mathrm{C}_{18}$ column. The gradient consisted of $0 \% \mathrm{~B}$ for $3.5 \mathrm{~min}$, then $0 \%-15 \%$ B over $35 \mathrm{~min}$ at $7 \mathrm{~mL} / \mathrm{min}$, where $\mathrm{A}=\mathrm{H}_{2} \mathrm{O}+0.1 \%$ TFA and $\mathrm{B}=$ acetonitrile $+0.1 \%$ TFA. $\mathrm{MAS}_{3}$ eluted at $\mathrm{R}_{\mathrm{t}}=$ 21.8 min using ELSD detection. Fractions containing product were pooled and lyophilized. $\mathrm{MAS}_{3}$ was obtained as a white powder in $57 \%$ isolated yield $(8.0 \mathrm{mg}, 20.5 \mu \mathrm{mol})$, with the expected mass confirmed by ES-TOF mass spectrometry, and a purity of $\geq 98 \%$.

Solid-Phase Labeling of $\mathrm{MAS}_{3}$ with ${ }^{\mathbf{9 9 m}} \mathrm{Tc}-$ Pertechnetate

One-hundred fifty microliters of a $50 \%$ slurry of Chelex 100 resin (Bio-Rad) in $50 \mathrm{mM}$ 2-(N-morpholino)ethanesulfonic acid (MES) buffer, $\mathrm{pH}$ 5.0, were added to an empty micro Bio-Spin (Bio-Rad) chromatography column, washed once with MES buffer, and centrifuged at $3,000 \mathrm{~g}$ for $10 \mathrm{~s} ; 1.2 \mathrm{mg}(3 \mu \mathrm{mol})$ of $\mathrm{MAS}_{3}$ were dissolved in $1 \mathrm{~mL}$ of water. One milligram $(4 \mu \mathrm{mol})$ of stannous (II) chloride dihydrate was dissolved in $1 \mathrm{~mL}$ of $10 \mathrm{mM} \mathrm{HCl}$. Then $100 \mu \mathrm{L}$ of $\mathrm{MAS}_{3}$ and $35 \mu \mathrm{L}$ of stannous chloride were mixed well and added to the Chelex resin. ${ }^{99 \mathrm{~m}} \mathrm{Tc}$-pertechnetate (185-370 MBq [5-10 mCi]) in $100 \mu \mathrm{L}$ of saline, eluted directly from a ${ }^{99} \mathrm{Mo}$ generator with saline, were added to the tube. The tube was capped, wrapped in parafilm, and boiled for $10 \mathrm{~min}$ in a water bath. ${ }^{99 \mathrm{~m}} \mathrm{Tc}$ loading of $\mathrm{MAS}_{3}$ was monitored by RP-HPLC using a $4.6 \times 75 \mathrm{~mm}$ Symmetry $\mathrm{C}_{18}$ column with a linear gradient from $0 \%$ to $60 \% \mathrm{~B}$ over $30 \mathrm{~min}$, starting 2 min after injection, at $1 \mathrm{~mL} / \mathrm{min}$, where $\mathrm{A}=10 \mathrm{mM}$ TEAA and $\mathrm{B}=$ absolute $\mathrm{MeOH}$. ${ }^{99 \mathrm{~m}} \mathrm{Tc}-\mathrm{MAS}_{3}$ eluted at $\mathrm{R}_{\mathrm{t}}=14.1 \mathrm{~min}$. In separate experiments, the limits of this reaction were determined to be $370 \mathrm{MBq}(10 \mathrm{mCi})$ ${ }^{99 \mathrm{~m}} \mathrm{Tc}$-pertechnetate and $1.3 \mu \mathrm{mol}$ of $\mathrm{MAS}_{3}$ using $150 \mu \mathrm{L}$ of $50 \%$ Chelex 100 slurry.

A 10-mg Oasis HLB cartridge (catalog no. 186000383) was activated using methanol, then $\mathrm{H}_{2} \mathrm{O}$, and equilibrated with $\mathrm{H}_{2} \mathrm{O}$,

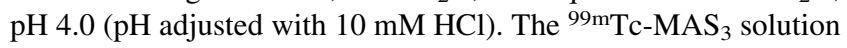
was diluted with $1 \mathrm{~mL}$ of $\mathrm{H}_{2} \mathrm{O}, \mathrm{pH} 4.0$, and bound to the cartridge. The cartridge was washed with $10 \mathrm{~mL}$ of $\mathrm{H}_{2} \mathrm{O}, \mathrm{pH} 4.0$, to remove ${ }^{99 \mathrm{~m}} \mathrm{Tc}$-pertechnetate, tin, and free $\mathrm{MAS}_{3}$; then it was purged completely with nitrogen. Finally, ${ }^{99 \mathrm{~m}} \mathrm{Tc}-\mathrm{MAS}_{3}$ was eluted with $400 \mu \mathrm{L}$ dry DMSO or DMF.

\section{Synthesis of [ ${ }^{99 m} \mathrm{Tc}_{\mathrm{MAS}}$-MAS}

After $200 \mu \mathrm{g}(0.7 \mu \mathrm{mol})$ of TSTU powder were placed in a 1.5mL Eppendorf tube, $185-370 \mathrm{MBq}(5-10 \mathrm{mCi})$ of purified ${ }^{99 \mathrm{~m}} \mathrm{Tc}-$ $\mathrm{MAS}_{3}$ in $400 \mu \mathrm{L}$ DMSO or DMF and $0.5 \mu \mathrm{L}(2.9 \mu \mathrm{mol})$ of neat (5.74 M) $N, N$-diisopropylethylamine (DIEA) were added. The top was sealed and the solution was incubated at $60^{\circ} \mathrm{C}$ for $10 \mathrm{~min}$. The reaction was diluted to $1 \mathrm{~mL}$ final volume by the addition of 600 $\mu \mathrm{L}$ of dichloromethane:hexane (6:4). The reactants and by-products were removed by passage through Waters Oasis MCX (catalog no. 186000252) and MAX (catalog no. 186000366) cartridges attached in tandem. The flow-through, containing pure [99m Tc-MAS 3 ]NHS ester, was concentrated by loading on an Oasis HLB cartridge, washing with of $1 \mathrm{~mL}$ of dichloromethane:hexane (6:4), and eluting using $500 \mu \mathrm{L}$ of either DMF or DMSO. The purity of the compound was assessed by RP-HPLC using a $4.6 \times$ $75 \mathrm{~mm}$ Symmetry $\mathrm{C}_{18}$ column with a linear gradient from $0 \%$ to $60 \% \mathrm{~B}$ over $30 \mathrm{~min}$, starting $2 \mathrm{~min}$ after injection, at $1 \mathrm{~mL} / \mathrm{min}$, where $\mathrm{A}=10 \mathrm{mM}$ TEAA and $\mathrm{B}=$ absolute $\mathrm{MeOH}$. [ ${ }^{99 \mathrm{~m}} \mathrm{Tc}-$ $\mathrm{MAS}_{3}$ ]-NHS eluted at $\mathrm{R}_{\mathrm{t}}=23.5 \mathrm{~min}$. The specific activity of

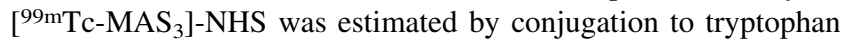


and measurement of 280-nm absorbance of the product using the same RP-HPLC conditions as those used to assess purity.

\section{Synthesis and Purification of Radiolabeled PSMA Ligands}

Covalent conjugation of GPI derivatives with [ ${ }^{99 \mathrm{~m}} \mathrm{Tc}^{\left.-\mathrm{MAS}_{3}\right]-}$ NHS was performed by the addition of $100 \mu \mathrm{L}(10 \mu \mathrm{mol})$ of 100 $\mathrm{mM}$ triethylamine in dry DMSO to $10 \mu \mathrm{L}(0.1 \mu \mathrm{mol})$ of a $10 \mathrm{mM}$ solution of GPI derivative in a total of $400 \mu \mathrm{L}$ dry DMF/DMSO, followed by the addition of $200 \mu \mathrm{L}$ of [ $\left.{ }^{99 \mathrm{~m}} \mathrm{Tc}-\mathrm{MAS}_{3}\right]-\mathrm{NHS}$ (185$259 \mathrm{MBq}[5-7 \mathrm{mCi}]$ ) in dry DMSO. Constant stirring at room temperature was maintained for $40-90 \mathrm{~min}$, until the reaction was completed. The radiolabeled ligands were analyzed by RP-HPLC on a $4.6 \times 75 \mathrm{~mm}$ Symmetry $\mathrm{C}_{18}$ column using a linear gradient from $0 \%$ to $60 \% \mathrm{~B}$ over $25 \mathrm{~min}$, beginning 2 min after injection, at a flow rate of $1 \mathrm{~mL} / \mathrm{min}$, where $\mathrm{A}=10 \mathrm{mM}$ TEAA, $\mathrm{pH} 7.0$, and $\mathrm{B}=$ absolute $\mathrm{MeOH}$.

\section{Synthesis of Re-MAS}

A procedure reported previously (9) was used with slight modification. $\mathrm{MAS}_{3}(4.8 \mathrm{mg}, 16 \mu \mathrm{mol})$ was dissolved in $1.5 \mathrm{~mL}$ of water. Stannous chloride dihydrate $(5.4 \mathrm{mg}, 24 \mu \mathrm{mol})$ in 1.5 $\mathrm{mL}$ of $0.1 \mathrm{M}$ citrate buffer, $\mathrm{pH} 5.0$, and $\mathrm{NaReO}_{4}(6.6 \mathrm{mg}, 24$ $\mu \mathrm{mol})$ in $1.5 \mathrm{~mL}$ of $\mathrm{H}_{2} \mathrm{O}$ were added to the $\mathrm{MAS}_{3}$ solution. The reaction mixture was stirred at $90^{\circ} \mathrm{C}$ for $1 \mathrm{~h}$. After cooling to room temperature, Re-MAS ${ }_{3}$ was purified on an Oasis HLB cartridge and eluted with DMSO. The purity was assessed by liquid chromatography/mass spectrometry (LC/MS) on a $4.6 \times 150$ $\mathrm{mm}$ Symmetry $\mathrm{C}_{18}$ column using a linear gradient from $0 \%$ to $50 \% \mathrm{~B}$ over $15 \mathrm{~min}$, beginning $2 \mathrm{~min}$ after injection, at a flow rate of $1 \mathrm{~mL} / \mathrm{min}$, where $\mathrm{A}=\mathrm{H}_{2} \mathrm{O}+0.1 \%$ formic acid and $\mathrm{B}=$ acetonitrile $+0.1 \%$ formic acid. Retention time was $6.4 \mathrm{~min}$.

\section{Synthesis of [Re-MAS 3 ]-NHS}

Fifty microliters $(3 \mu \mathrm{mol})$ of a $60 \mathrm{mM}$ TSTU solution in DMSO and $200 \mu \mathrm{L}(2 \mu \mathrm{mol})$ of a $10 \mathrm{mM} \mathrm{Re}-\mathrm{MAS}_{3}$ solution in DMSO were mixed together; then $25 \mu \mathrm{L}(5 \mu \mathrm{mol})$ of $200 \mathrm{mM}$ $N, N$-diisopropylethylamine and $25 \mu \mathrm{L}$ of DMSO were added. The solution was vortexed at room temperature for $40 \mathrm{~min}$. After dilution with dichloromethane, the NHS ester was purified using Oasis MCX, MAX, and HLB cartridges connected in series as described earlier. The purity was assessed by LC/MS on a $4.6 \times$ $150 \mathrm{~mm}$ Symmetry $\mathrm{C}_{18}$ column using a linear gradient from $0 \%$ to $50 \% \mathrm{~B}$ over $15 \mathrm{~min}$, beginning $2 \mathrm{~min}$ after injection, at a flow rate of $1 \mathrm{~mL} / \mathrm{min}$, where $\mathrm{A}=\mathrm{H}_{2} \mathrm{O}+0.1 \%$ formic acid and $\mathrm{B}=$ acetonitrile $+0.1 \%$ formic acid. Retention time was $10.4 \mathrm{~min}$.

\section{Synthesis and Purification of [Re-MAS $\left.{ }_{3}\right]$-Conjugates}

Covalent conjugation of GPI derivatives with [Re-MAS 3 ]-NHS was performed by the addition of $0.1 \mathrm{~mL}(10 \mu \mathrm{mol})$ of $100 \mathrm{mM}$ triethylamine in dry DMSO to $0.1 \mathrm{~mL}(1 \mu \mathrm{mol})$ of a $10 \mathrm{mM}$ solution of GPI derivatives in dry DMSO or DMF, followed by addition of $0.2 \mathrm{~mL}(2 \mu \mathrm{mol})$ of a $10 \mathrm{mM}\left[\mathrm{Re}-\mathrm{MAS}_{3}\right]-\mathrm{NHS}$ solution in dry DMSO. Constant stirring at room temperature was maintained for $2 \mathrm{~h}$. The conjugates were purified by preparative HPLC (Symmetry $\mathrm{C}_{18}$ column, $19 \times 150 \mathrm{~mm}, 7 \mu \mathrm{m}$ ) using a linear gradient from $0 \%$ to $50 \% \mathrm{~B}$ over $27 \mathrm{~min}$, starting $5 \mathrm{~min}$ after injection, with a flow rate of $10 \mathrm{~mL} / \mathrm{min}$. The collected fractions were lyophilized, and purity was assessed by LC/MS on a $4.6 \times$ $150 \mathrm{~mm}$ Symmetry $\mathrm{C}_{18}$ column using a linear gradient from $0 \%$ to $50 \%$ B over $15 \mathrm{~min}$, beginning $2 \mathrm{~min}$ after injection, at a flow rate of $1 \mathrm{~mL} / \mathrm{min}$, where $\mathrm{A}=\mathrm{H}_{2} \mathrm{O}+0.1 \%$ formic acid and $\mathrm{B}=$ acetonitrile $+0.1 \%$ formic acid.

\section{Quantification of Serum Stability}

The stabilities of [ ${ }^{99 \mathrm{~m}} \mathrm{Tc}-\mathrm{MAS}_{3}$ ]-GPI compounds were tested by incubation in the absence (phosphate-buffered saline [PBS] only) or presence of $100 \%$ calf serum for $4 \mathrm{~h}$ at $37^{\circ} \mathrm{C}$. Stability and transmetallation were quantified using high-resolution chromatography. For PBS experiments, a $4.6 \times 75$ Symmetry $\mathrm{C}_{18}$ column was used as described earlier for radiolabeled PSMA ligands. For serum experiments, an $8 \times 300 \mathrm{~mm}, 200-\AA$ Diol (YMC, catalog no. DL20S053008WT) gel-filtration column was used with PBS as the mobile phase. Gel-filtration molecular weight (M.W.) markers (Bio-Rad) were: $\mathrm{M}_{1}=$ thyroglobulin $(670 \mathrm{kDa}), \mathrm{M}_{2}=\gamma$-globulin $(158 \mathrm{kDa}), \mathrm{M}_{3}=$ ovalbumin $(44 \mathrm{kDa}), \mathrm{M}_{4}=\operatorname{myoglobin}(17 \mathrm{kDa})$, and $\mathrm{M}_{5}=$ vitamin $\mathrm{B}_{12}(1.3 \mathrm{kDa})$.

\section{High-Throughput, Radioactive Live Cell Binding and Affinity Assay}

Human prostate cancer cell lines, PSMA-positive LNCaP and PSMA-negative PC-3, were obtained from the American Type Culture Collection. The PSMA-negative human bladder cancer cell line TsuPR1 was a generous gift of Dr. John T. Isaacs (Johns Hopkins University, Baltimore, MD). Cell lines were cultured at $37^{\circ} \mathrm{C}$ under humidified $5 \% \mathrm{CO}_{2}$ in RPMI 1640 medium (Mediatech Cellgro) supplemented with $10 \%$ fetal bovine serum (Gemini BioProducts) and 5\% penicillin/streptomycin (Cambrex Bioscience). Cells were split onto 96-well filter plates (model MSHAS4510; Millipore) and grown to 50\% confluence (approximately 35,000 cells per well) over $48 \mathrm{~h}$.

To assign absolute affinity to each compound, a homologous competition assay was used with the ${ }^{99 \mathrm{~m}} \mathrm{Tc}$-labeled version as the tracer and the relabeled version as the test compound. To avoid internalization of the radioligand due to constitutive endocytosis (2), live cell binding was performed at $4^{\circ} \mathrm{C}$. Cells were washed 2 times with ice-cold Tris-buffered saline (TBS), pH 7.4, and incubated for $20 \mathrm{~min}$ at $4^{\circ} \mathrm{C}$ with $0.02 \mathrm{MBq}(0.5 \mu \mathrm{Ci})$ of radiotracer in the presence or absence of the test compound. Cells were then washed 3 times with TBS using a Millipore vacuum manifold (catalog no. MSVMHTS00), and the well contents was transferred directly to $12 \times 75 \mathrm{~mm}$ plastic tubes placed in $\gamma$-counter racks. Transfer was accomplished using a modified (Microvideo Instruments) 96-well puncher (MAMP09608; Millipore) and disposable punch tips (MADP19650; Millipore). Well contents were counted on a model 1470 Wallac Wizard (Perkin Elmer) 10-detector $\gamma$-counter, and curves were fit using Prism version 4.0a (GraphPad) software.

\section{Near-Infrared (NIR) Fluorescence and $\gamma$-Radioscintigraphic Imaging}

To assess viability and to verify confluence, living cells were loaded with the NIR fluorophore IR-786 by adding it to the cell culture medium at $1 \mu \mathrm{M}$ for $30 \mathrm{~min}$ at $37^{\circ} \mathrm{C}$ before the start of the experiment (10). Cells were incubated as described earlier with 3.7 MBq $(100 \mu \mathrm{Ci})$ of ${ }^{99 \mathrm{~m}} \mathrm{Tc}-$ labeled compound per well, in the buffer being tested, for $20 \mathrm{~min}$ at $4^{\circ} \mathrm{C}$, before extensive washing of the filter plate. Simultaneous white light and NIR fluorescence imaging of plates was performed as described in detail previously $(11,12)$. $\gamma$-Radioscintigraphy was performed with an Isocam Technologies Research Digital Camera equipped with a $1 / 2-$ in. $\mathrm{NaI}$ crystal, 86 photomultiplier tubes, and a high-resolution, lowenergy lead collimator. 


\section{RESULTS}

\section{High-Affinity, Multimeric Small Molecules for} Targeting PSMA

Our group has previously developed a high-affinity ( $9 \mathrm{nM})$, monomeric small molecule (311 Da) termed GPI, which is engineered to bind the active site of PSMA (2). Unfortunately, inorganic anions in serum-such as phosphatecompete with monomeric GPI, rendering it marginal for use as an in vivo diagnostic (2). The work of Whitesides and colleagues (13) suggests that by decreasing the off-rate, multivalency can permit a small molecule to "out-compete" endogenous competitors. To test this hypothesis, while maintaining overall small size, we have developed a tri-NHS ester derivative of adamantane (14), which permits conjugation of up to 3 targeting ligands (such as GPI) in addition to a contrast agent or radiotracer. Recently, we have added a 6-carbon linker to improve radiotracer conjugation and have purified a series of GPI derivatives with increasing valency (Fig. 1). As shown in Table 1, conversion of monomeric GPI (I) to an adamantane trimer (IV) results in an affinity improvement of over 1.5 logarithms and retention of affinity in $100 \%$ serum.

\section{Solid-Phase Prelabeling for Preparation of 99mTc-MAS 3 Conjugates}

Unfortunately, highly anionic small molecules such as IV are difficult to use as ${ }^{99 \mathrm{~m}} \mathrm{Tc}$ diagnostic radiotracers because the 12 net negative charges after conjugation to a chelator can potentially act as coligands for ${ }^{99 \mathrm{~m}} \mathrm{Tc}$. Furthermore, traditional pre- and postlabeling approaches for ${ }^{99 \mathrm{~m}} \mathrm{Tc}$ (Fig. 2A) involve the use of excess quantities of an exchange ligand such as $\mathrm{Na}^{+} / \mathrm{K}^{+}$tartrate. This creates 2 major problems. First, separation of ${ }^{99 \mathrm{~m}}$ Tc-tartrate away from a desired radiolabeled chelator is extremely difficult and requires high-resolution HPLC (Fig. 2B). For this reason, the radiolabeled tartrate peak is typically just accepted as "contaminant" and the entire labeling reaction is used (even in clinical settings). Second, nonradioactive exchange ligand is used in excess, hence, all subsequent chemical steps, such as solution-phase prelabeling (Fig. 2A) are competed by the exchange ligand's carboxylic acids, unless great care, and time-consuming separation, is used. Finally, if not purified to completion, nonradioactive tartrate can form reactive NHS esters and conjugate covalently to the targeting ligand, again requiring careful purification, and risking competition with radiotracer.

To solve the problems associated with traditional radiolabeling, we have developed a simple and rapid, cartridge-based method for converting readily available and inexpensive ${ }^{99 \mathrm{~m}} \mathrm{Tc}$-pertechnetate $\left(\mathrm{Na}^{99 \mathrm{~m}} \mathrm{TcO}_{4}\right)$ into a chemically pure, reactive NHS ester in organic solvent (Fig. 2C). The first key to this strategy is the elimination of soluble exchange ligand in favor of a solid-phase source of carboxylic acids (Chelex 100 resin). As described in detail
FIGURE 1. Highly anionic PSMAtargeting small-molecule ligands: chemical structures and M.W. for PSMA-targeting ligands used in this study.

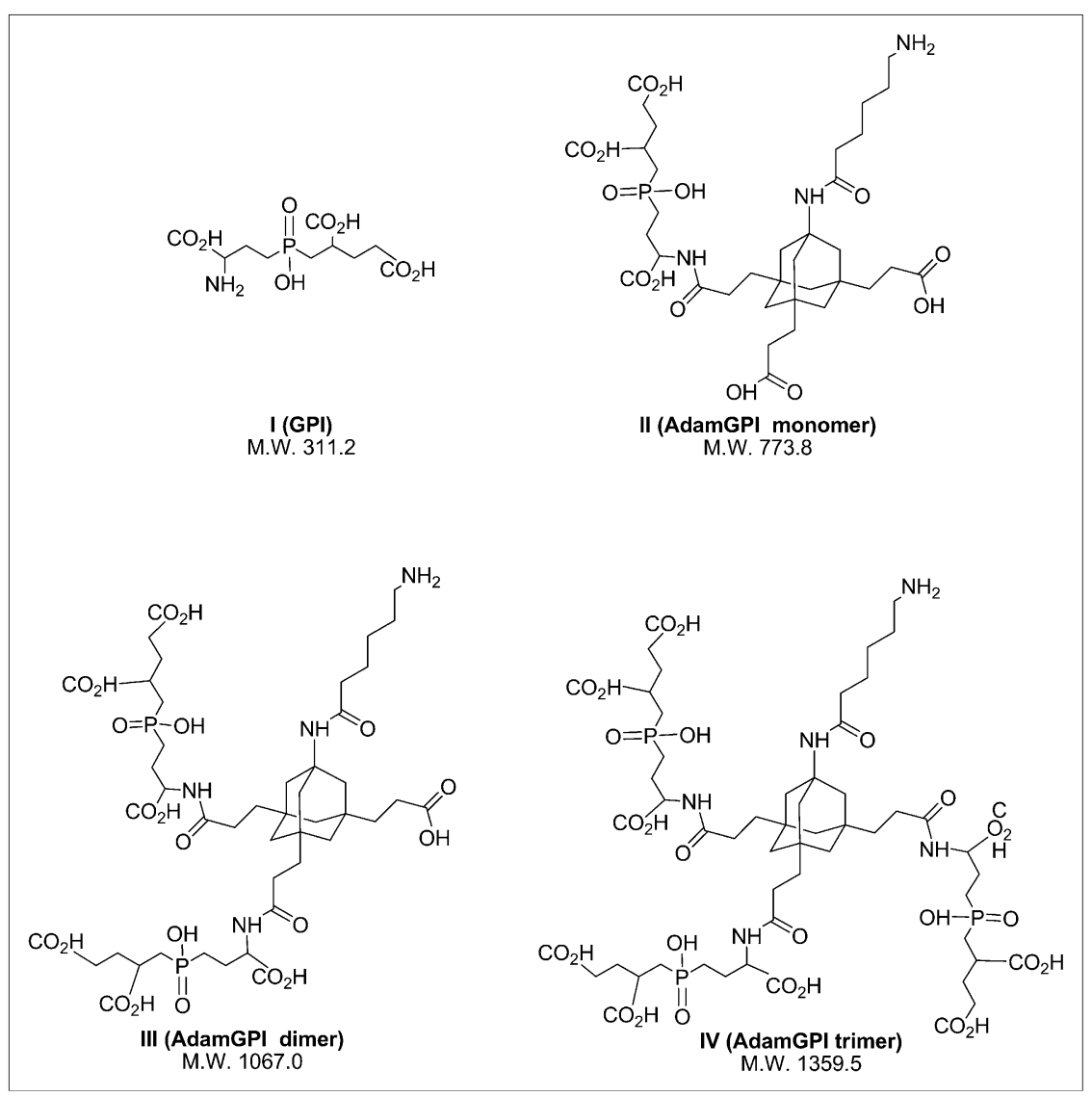


TABLE 1

Live Cell-Binding Affinity of Small Molecules Targeted to PSMA

\begin{tabular}{|c|c|c|c|c|c|c|c|c|c|c|}
\hline \multirow[b]{2}{*}{ Molecule } & \multirow[b]{2}{*}{ Description } & \multirow[b]{2}{*}{$\begin{array}{c}\text { Metal } \\
\text { conjugate }\end{array}$} & \multirow[b]{2}{*}{ M.W. } & \multirow[b]{2}{*}{$\begin{array}{c}\text { Net charge } \\
(\mathrm{pH} 7.0)\end{array}$} & \multirow[b]{2}{*}{$\begin{array}{c}\text { Charge-to-mass } \\
\text { ratio }\left(\times 10^{-3}\right)\end{array}$} & \multicolumn{5}{|c|}{ Live cell-binding affinity $(\mathrm{nM})^{\star}$} \\
\hline & & & & & & $\begin{array}{c}\text { LNCaP } \\
\text { cells } \\
\text { (TBS) }\end{array}$ & $\begin{array}{c}\text { LNCaP } \\
\text { cells } \\
\text { (PBS) }\end{array}$ & $\begin{array}{c}\text { LNCaP } \\
\text { cells } \\
\text { (serum) }\end{array}$ & $\begin{array}{c}\text { PC-3 } \\
\text { cells } \\
\text { (TBS) }\end{array}$ & $\begin{array}{c}\text { TsuPR1 } \\
\text { cells } \\
\text { (TBS) }\end{array}$ \\
\hline I & GPI & None & 311.2 & -3 & -9.6 & $10.4 \pm 0.3$ & ND & ND & ND & ND \\
\hline la & GPI & Re-MAS 3 & 844.7 & -4 & -4.7 & $35.5 \pm 0.1$ & ND & ND & ND & ND \\
\hline Ila & $\begin{array}{l}\text { AdamGPI } \\
\text { monomer }\end{array}$ & $\mathrm{Re}-\mathrm{MAS}_{3}$ & $1,307.3$ & -6 & -4.6 & $31.3 \pm 0.4$ & ND & ND & ND & ND \\
\hline Illa & AdamGPI dimer & $\mathrm{Re}-\mathrm{MAS}_{3}$ & $1,600.5$ & -9 & -5.6 & $14.4 \pm 1.4$ & $20.3 \pm 1.5$ & $17.4 \pm 1.0$ & ND & ND \\
\hline IV & AdamGPI trimer & None & $1,359.5$ & -11 & -8.1 & $0.4 \pm 0.1$ & $0.5 \pm 0.2$ & $0.7 \pm 0.2$ & ND & ND \\
\hline IVa & AdamGPI trimer & Re-MAS ${ }_{3}$ & $1,893.5$ & -12 & -6.3 & $3.3 \pm 0.1$ & $2.9 \pm 0.1$ & $2.1 \pm 0.1$ & ND & ND \\
\hline
\end{tabular}

${ }^{*}$ Mean affinity $\pm 95 \%$ confidence interval from 3 independent experiments is shown.

ND $=$ None detected.

earlier, only $8 \mathrm{~min}$ is required to fully load (99\% radiochemical yield) a ${ }^{99 m} \mathrm{Tc}$ chelator, such as $\mathrm{MAS}_{3}(9)$, with ${ }^{99 \mathrm{~m}} \mathrm{Tc}$ (Fig. 2C). $\mathrm{MAS}_{3}$ was chosen over $\mathrm{MAG}_{3}$ and other ${ }^{99 \mathrm{~m}} \mathrm{Tc}$ chelates given its low-background binding in primates after conjugation to targeting molecules (15).
The second key to this strategy is the transfer of ${ }^{99 \mathrm{~m} T c-}$ $\mathrm{MAS}_{3}$ from aqueous buffer to nonaqueous buffer, as the final NHS ester is highly susceptible to attack by the hydroxyl ion of $\mathrm{H}_{2} \mathrm{O}$. To accomplish this, and to remove unwanted molecules, the supernatant from the Chelex 100

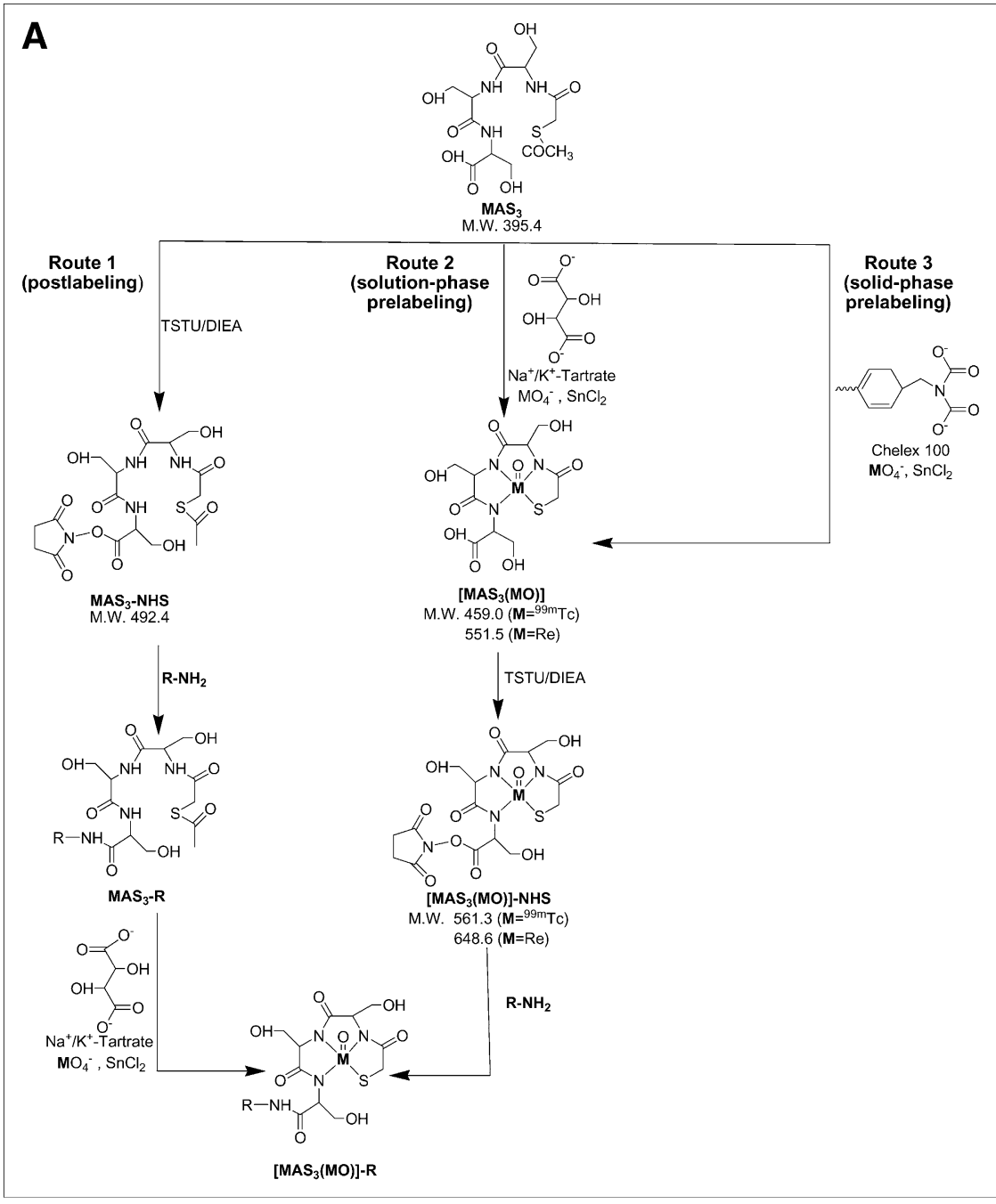

FIGURE 2. ${ }^{99 m}$ Tc labeling strategies, solid-phase prelabeling, and purification of ${ }^{99 m}$ Tc-/Re-labeled $\mathrm{MAS}_{3}$ and $\mathrm{MAS}_{3}-$ NHS. (A) General approaches for creating 99mTc-radiolabeled derivatives of small molecules and peptides include postlabeling (route 1) in presence of excess exchange ligand such as tartrate, solutionphase prelabeling using excess of exchange ligand (route 2), or solid-phase prelabeling (route 3) using Chelex 100 resin as described. (B) $\mathrm{C}_{18}$ HPLC radiochromatograms of conventional solution-

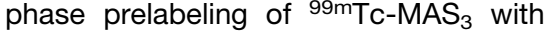
excess tartrate (top left) and solid-phase prelabeling with Chelex 100 (bottom left). Solid-phase formation and purification

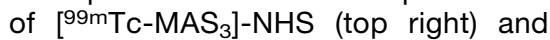
hydrolysis of NHS ester at $\mathrm{pH} 10$ (bottom

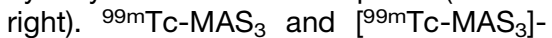
NHS elute at 14.1 and $23.5 \mathrm{~min}$, respectively. ${ }^{99 \mathrm{mTc}-T a r t r a t e}$ elutes at $13.5 \mathrm{~min}$. (C) Simple, cartridge-based labeling and purification protocol to produce [ ${ }^{99 m T c-}$ $\mathrm{MAS}_{3}$ ]-NHS is shown. Total elapsed time (brackets) and yield for each step are also shown. (D) $\mathrm{C}_{18}$ HPLC ELSD tracings (top) and mass spectra of major peak (bottom) for Re-MAS 3 (left) and its NHS ester (right). Expected isotopic patterns for these Re derivatives are shown as insets. $\mathrm{AU}=$ absorbance units. 


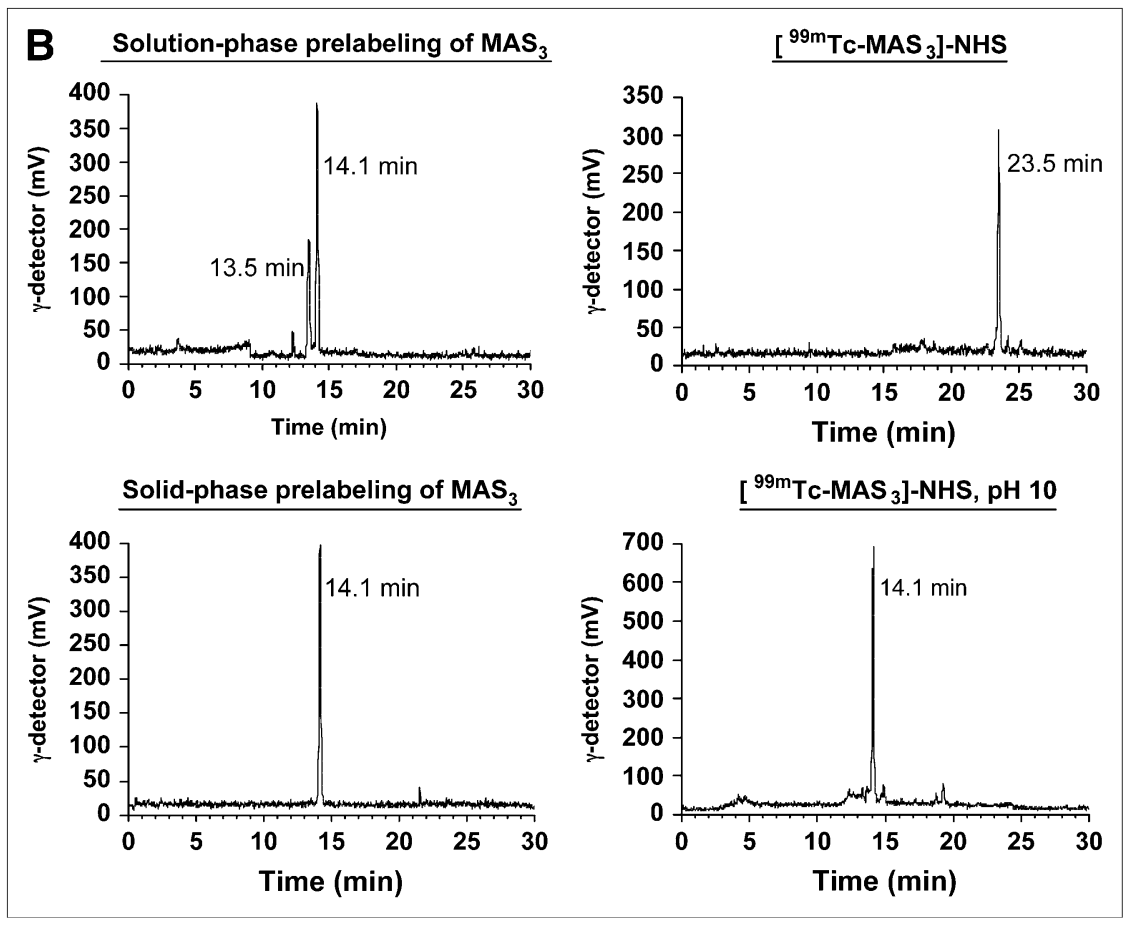

FIGURE 2. (Continued)

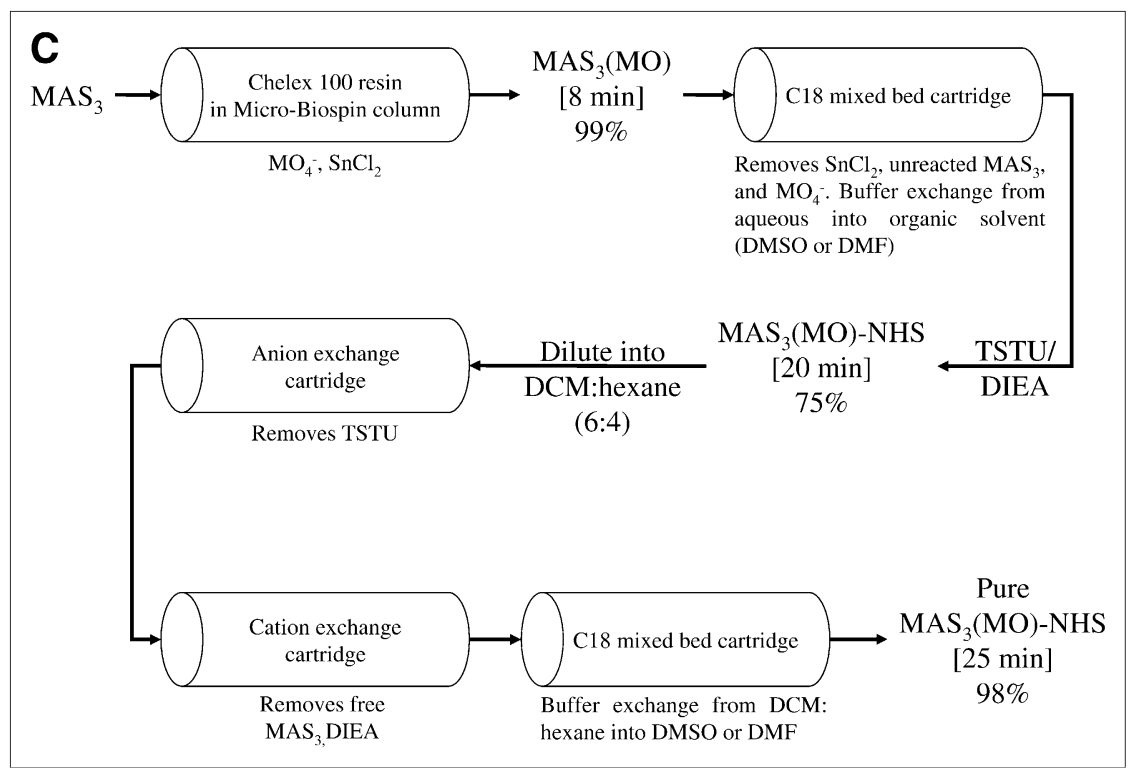

resin is bound to a $\mathrm{C}_{18}$ mixed-bed cartridge, washed, and then eluted with desired organic solvent (DMSO or DMF). The NHS ester of ${ }^{99 m}{ }^{9 c}-M_{A S}$ is then formed rapidly using TSTU and DIEA as described. Excess reactants are removed using tandem mixed-mode anion-exchange and cation-exchange cartridges, and the final product is concentrated on a $\mathrm{C}_{18}$ mixed-bed cartridge (Fig. 2C). Using this chemical strategy, $\left[{ }^{99 \mathrm{~m}} \mathrm{Tc}-\mathrm{MAS}_{3}\right]-\mathrm{NHS}$ is prepared in ultrapure form (>99\%; Fig. 2B) in DMSO or DMF, in only $25 \mathrm{~min}$, with an overall radiochemical yield of 70\%-75\% relative to ${ }^{99 \mathrm{~m}} \mathrm{Tc}$-pertechnetate starting material. Reaction of the final product with basic water $(\mathrm{pH} 10)$ results in the

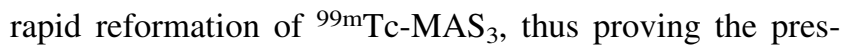
ence of an NHS ester (Fig. 2B). The typical specific activity of $\left[{ }^{99 \mathrm{~m}} \mathrm{Tc}-\mathrm{MAS}_{3}\right]-\mathrm{NHS}$ produced using this strategy was $4.1 \times 10^{8} \mathrm{MBq} / \mathrm{mmol}\left(1.1 \times 10^{4} \mathrm{Ci} / \mathrm{mmol}\right)$.

To confirm, absolutely, the chemical structures produced, as well as to prepare nonradioactive derivatives of diagnostic agents for affinity measurements, the chemistry was repeated using Re. Although the exact procedure shown in Figure $2 \mathrm{C}$ worked well for Re-MAS 3 chelates, the yield was low $(\approx 20 \%)$, likely reflecting the difficulty others have had in preparing Re chelates (8). Hence, for preparative purification of Re-MAS ${ }_{3}$, solution-phase labeling was used, 


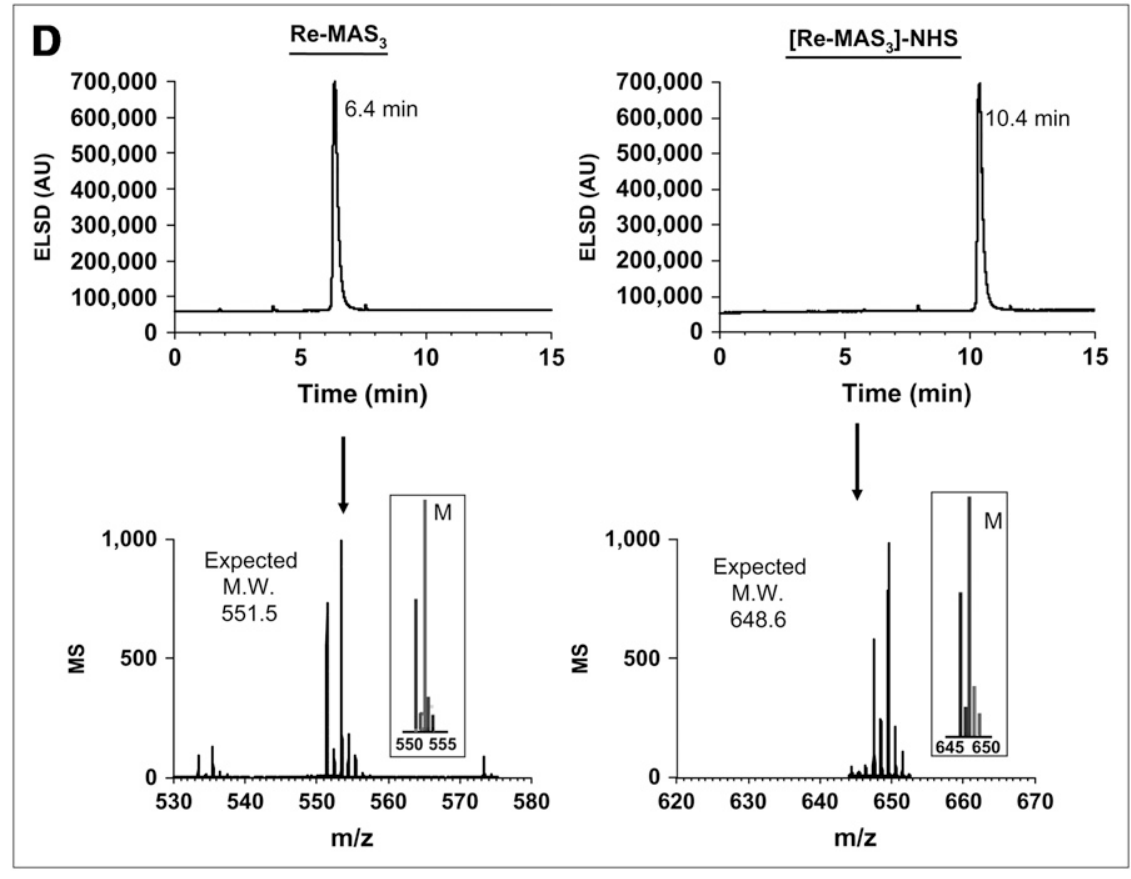

FIGURE 2. (Continued)

followed by formation and purification of [Re-MAS 3 -NHS using our solid-phase approach. A high-resolution LC/MS HPLC system (7) was also used to verify that all cartridges performed as designed and to verify the purity of final compounds (Fig. 2D).

\section{Solid-Phase Prelabeling of Highly Anionic PSMA Small Molecules}

Using this solid-phase preloading strategy, GPI-containing molecules of increasing ligand valency were labeled with either ${ }^{99 \mathrm{~m}} \mathrm{Tc}$ or Re in 1 chemical step as shown in Figure $3 \mathrm{~A}$. For ${ }^{99 \mathrm{~m}} \mathrm{Tc}$-labeled molecules, no further purification was necessary, as the NHS ester reaction with an amine in dry DMSO or DMF goes to completion without side reactions (Fig. 3B). For Re-labeled molecules, which were to be used for affinity measurements, LC/MS analysis with ELSD (7) was used to ensure the highest possible purity and to confirm the expected isotopic pattern (Fig. 3B).

The stability of adamantine-trimerized GPI molecule (IVa) was tested by incubation at $37^{\circ} \mathrm{C}$ for $4 \mathrm{~h}$ in either PBS or $100 \%$ serum. HPLC analysis (Fig. 3C) revealed $100 \%$ stability in PBS and 99\% stability in serum, with $1 \%$ appearing as an early-eluting peak.

\section{Bioactivity and Radioscintigraphic Imaging of PSMA-Specific Radiotracers}

Using the nonradioactive $\mathrm{Re}$ derivatives as test compounds, ${ }^{99 \mathrm{~m} T c}$ derivatives as radiotracers, and a highthroughput 96-well filter plate assay (7), the absolute affinity of each molecule for the surface of living prostate cancer cells was measured using homologous competition (Table 1). Actual raw data from the assay using monomeric [99m Tc-MAS 3 -GPI (Ia) as radiotracer (Fig. 3D, top) and trimeric [ ${ }^{99 \mathrm{~m}} \mathrm{Tc}-\mathrm{MAS}_{3}$ ]-AdamGPI (IVa) as radiotracer (Fig. $3 \mathrm{D}$, bottom) confirm that both phosphate and serum compete effectively with monomeric radiotracers for the active site of PSMA but are unable to compete with trimeric radiotracers, resulting in nearly identical affinities of IVa under all physiologic conditions. The measured maximum number of binding sites $\left(\mathrm{B}_{\max }\right)$ values for compounds $\mathrm{Ia} /$ IIa, IIIa, and IVa were $1.6 \times 10^{5}, 2.1 \times 10^{5}$, and $2.6 \times 10^{5}$ PSMA receptors per cell, respectively, which is consistent with previously published reports of $1.8 \times 10^{5}$ to $8.0 \times 10^{5}$ for PSMA-specific monoclonal antibodies $(16,17)$.

To confirm that the synthesized radiotracers permit sensitive and specific radioscintigraphic imaging of prostate cancer cells, approximately 35,000 PSMA-positive (LNCaP) or PSMA-negative (PC-3 and TsuPR1) cancer cells were grown in each well of a 96-well filter plate and incubated at $4^{\circ} \mathrm{C}$ for $20 \mathrm{~min}$ with the indicated tracer. As shown in Figure 4, and confirming the results in Table 1 and Figure 3D, ${ }^{99 m}$ Tc-labeled trimeric AdamGPI (IVa) bound with high affinity to living prostate cancer cells expressing PSMA in all buffers, including $100 \%$ serum, and no binding was detectable on PSMA-negative cells.

\section{DISCUSSION}

Patients with prostate and other cancers are in desperate need of targeted diagnostic and therapeutic agents. One common strategy for the development of such agents is to use a small molecule or peptide-targeting ligand, conjugated to a desired functional molecule (e.g., contrast agent, radiotracer, or therapeutic) via an isolating linker (7). This robust strategy requires conjugation chemistry that is simple and rapid. Although other pre- and postlabeling 


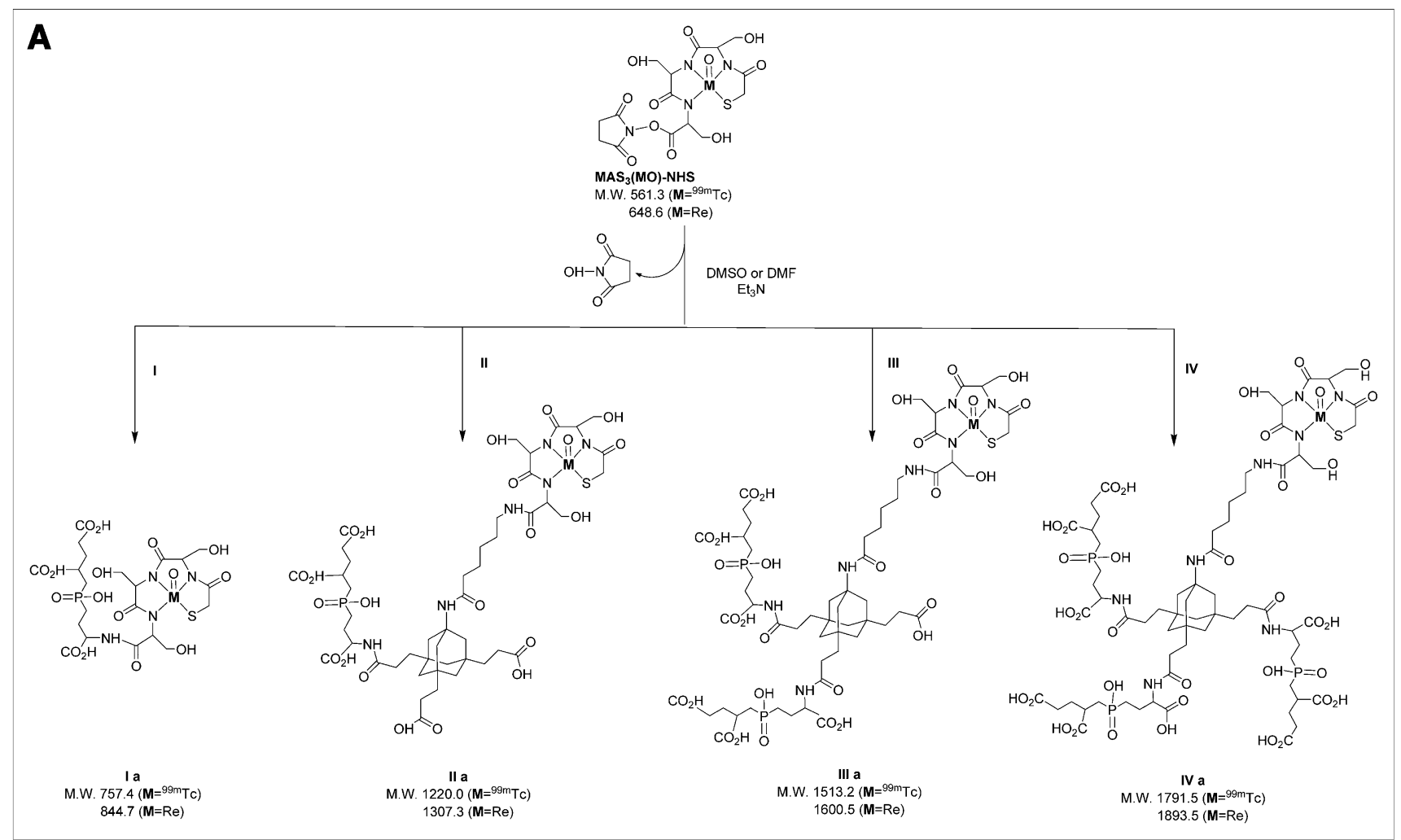

FIGURE 3. Preparation, purification, and analysis of PSMA-specific radiotracers. (A) Single nucleophiles (primary amines) of small molecules from Fig. 1 were conjugated in 1 step to [ ${ }^{99 m T c}-\mathrm{MAS}_{3}$ ]-NHS using solid-phase preloading strategy described in text to create PSMA-specific radiotracers. (B) RP-HPLC analysis of compounds I-IV after solid-phase prelabeling using either ${ }^{99 m T c}$ (left) or $\mathrm{Re}$ (right). $\mathrm{R}_{\mathrm{t}}$ values for compounds la-IVa are shown, as are ES-TOF(-) mass spectra of peak for Re compounds (insets). AU = absorbance units. For comparison, $\mathrm{R}_{\mathrm{t}}$ values for [ ${ }^{\left.99 \mathrm{~m} T \mathrm{~T}-\mathrm{MAS}_{3}\right]-\mathrm{NHS} \text { and }[\text { Re-MAS }} \mathrm{MHS}_{3}$-NH on their optimized gradients are 23.5 and $10.4 \mathrm{~min}$, respectively (Figs. 2B and 2D). (C) Serum protein binding and serum stability of solid-phase prelabeled ${ }^{99 m T c}$ PSMAspecific small molecules. Compound ${ }^{99 \mathrm{mTC}-I V a}$ was incubated for 0 or $4 \mathrm{~h}$ at $37^{\circ} \mathrm{C}$ in PBS (top) or $100 \%$ serum (bottom) and then subjected to HPLC analysis. Samples in PBS were resolved on a Symmetry $\mathrm{C}_{18}$ column. Samples in serum were resolved on a $120-\AA$ high-resolution gel-filtration column and also include absorbance $(280 \mathrm{~nm})$ tracings. $R_{t}$ values for gel-filtration markers $M_{1}-M_{5}$ are shown as arrows. Marker $R_{t}$ values were $M_{1}=6.6 \min , M_{2}=8.2 \min , M_{3}=9.2 \min , M_{4}=11.1 \mathrm{~min}$, and $M_{5}=13.4 \min$. (D) Live cell-binding assay. PSMA-positive LNCaP cells grown on 96-well filter plates as described in text were incubated for

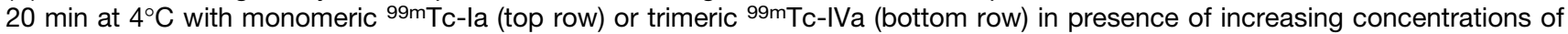
homologous nonradioactive test compound. Shown are results for monomeric Re-la (top row) and trimeric Re-IVa (bottom row) in TBS (left), PBS (middle), and 100\% serum (right). Also shown are mean affinities $\pm 95 \%$ confidence intervals for 3 independent assays. N.D. = none detected.

strategies for preparing ${ }^{99 \mathrm{~m}} \mathrm{Tc}$ SPECT radiotracers have been described $(8,18)$, none has the combined features of taking $<1 \mathrm{~h}$ with inexpensive disposable cartridges, eliminating exchange ligand contaminants, producing ultrapure reactive NHS esters in organic solvent, producing highspecific-activity radiotracers, producing a stable amide bond, and eliminating the need for HPLC purification of final labeled agents. Eliminating the need for any HPLC purification steps makes the strategy amenable to highthroughput small molecule and peptide screening and will also hopefully enable SPECT-especially, preclinical SPECT - by investigators who would otherwise not have access to the expensive equipment and chemistry expertise needed with other approaches. Another key feature is that it begins with ${ }^{99 \mathrm{~m}} \mathrm{Tc}$-pertechnetate, an inexpensive reagent available at virtually every medical center. Finally, our solid-phase strategy is inherently automatable.
An important general limitation of NHS ester chemistry is that the hydroxyl ion of water is a potent competitor. NHS esters of fluorophores are typically used in millimolar concentrations and in excess of the targeting molecule. This is not true of radioactive NHS esters, such as [ ${ }^{99 \mathrm{~m}} \mathrm{Tc}^{\left.-\mathrm{MAS}_{3}\right]-}$ NHS, which are used in nanomolar concentrations. Hence, the use of [ $\left.{ }^{99 m} \mathrm{Tc}^{-M A S_{3}}\right]-\mathrm{NHS}$ in aqueous buffer will result in low labeling efficiencies. When used in dry organic solvent, however, [ ${ }^{99 \mathrm{~m}} \mathrm{Tc}-\mathrm{MAS}_{3}$ ]-NHS reacts rapidly and completely with primary amines. Another potential limitation is the availability of the nucleophile within the targeting ligand. Each of our GPI derivatives has been engineered to have a flexible 6-carbon spacer; however, more sterically hindered amines could be difficult to conjugate.

Even with careful chemical engineering, small molecule and peptide-targeting ligands often have poor affinity or are competed by endogenous ligands. A general approach to 

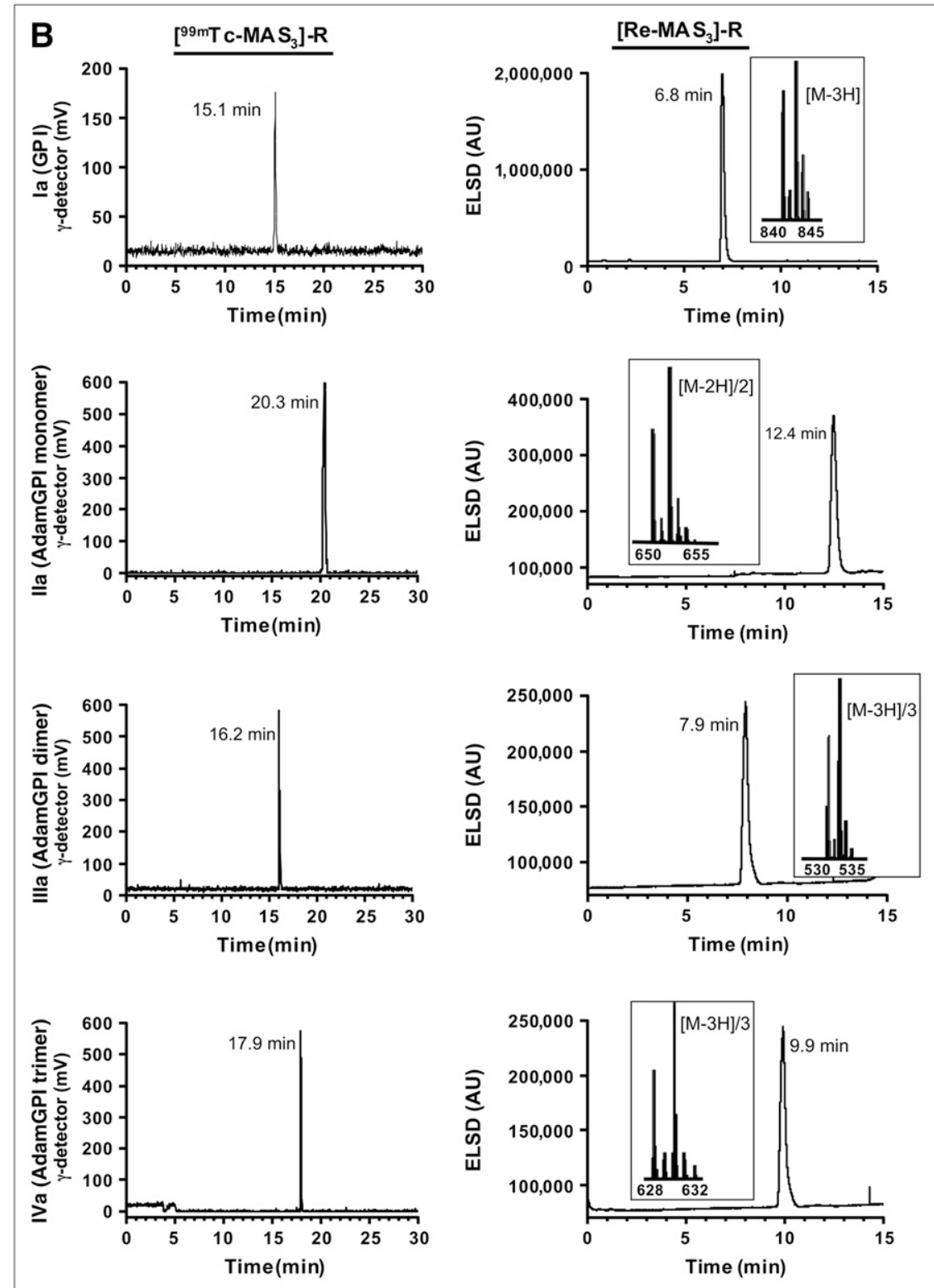

FIGURE 3. (Continued)

solving these problems was proposed by Whitesides' group (13) and involves multimerizing binding epitopes into an optimally spaced rigid structure. To accomplish this, we have created a tri-NHS adamantane derivative (14), which permits the conjugation of up to 3 (same or different) targeting ligands. The molecule also has an isolating linker and a deprotectable primary amine for subsequent conjugation to contrast agents, radiotracers, or therapeutics. Adamantane, being the core structure in diamond, has maximal rigidity. In this study, we conjugated GPI through a propionyl acid spacer and made no attempt to optimize intermolecular spacing or overall rigidity. Future studies will focus on these issues.

Nonetheless, the results to date are encouraging. First, conjugation of a single GPI monomer to a single adamantane core had only a negligible effect on affinity (Table 1; compare Ia with IIa). Second, increasing multivalency from 1 to 3 led to dramatic improvements in both affinity and competition with endogenous anions. Indeed, affinity not only increased almost 2 logarithms when measured in TBS, but as a trimer was unaffected by serum (Table 1). The results also reveal, however, that the GPI molecules are not as isolated from the effect of metal chelate as one would like. For example, when Re-MAS 3 is conjugated to either GPI monomer or AdamGPI Trimer, there is a 3- to 8-fold decrease in affinity. Nevertheless, the final affinity of IVa ( $3 \mathrm{nM}$ ) is equivalent to that of previously described PSMA monoclonal antibodies (16).

Because it is known that PSMA undergoes both constitutive and inducible endocytosis (19), we were careful to 

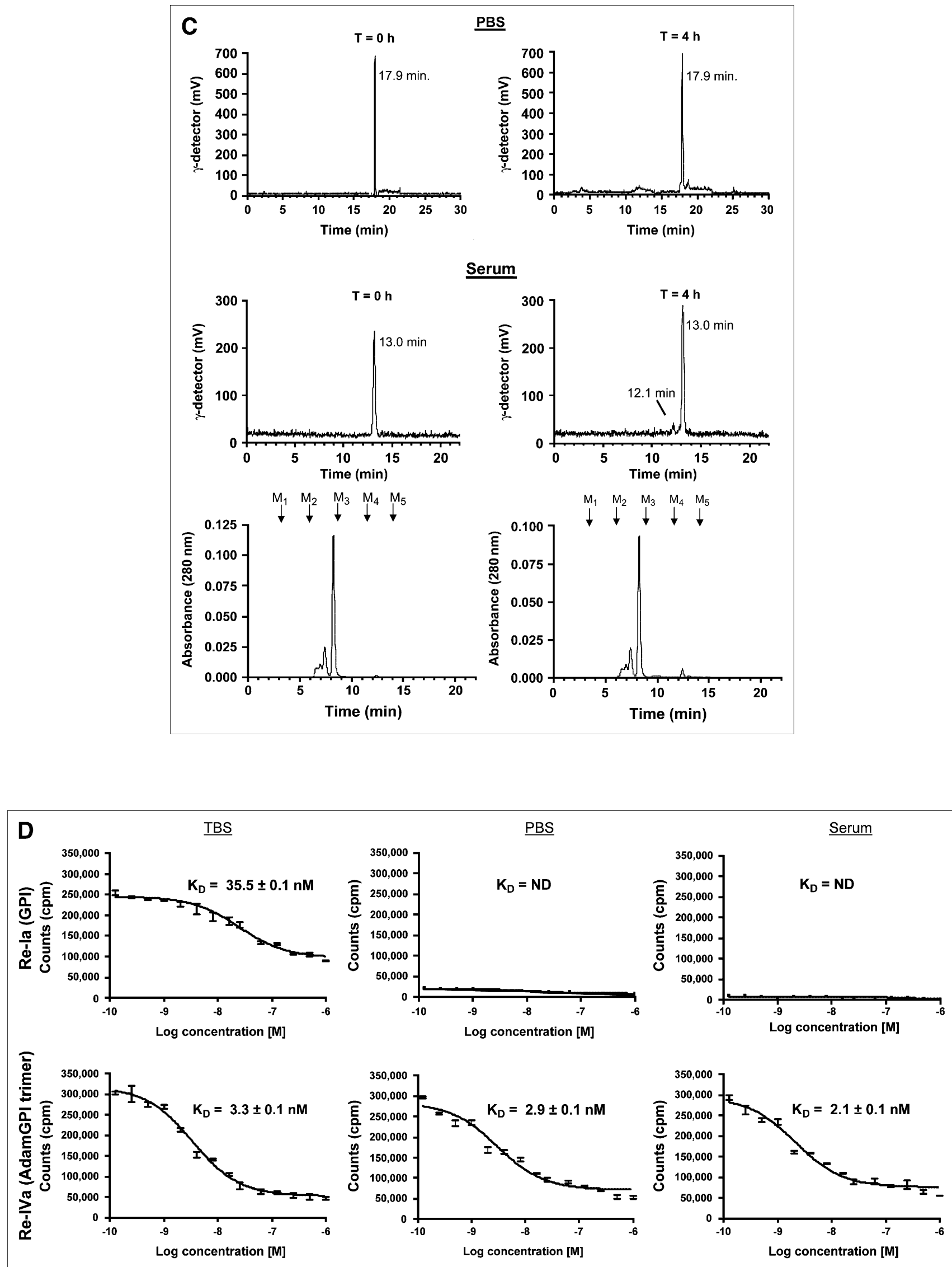

FIGURE 3. (Continued) 


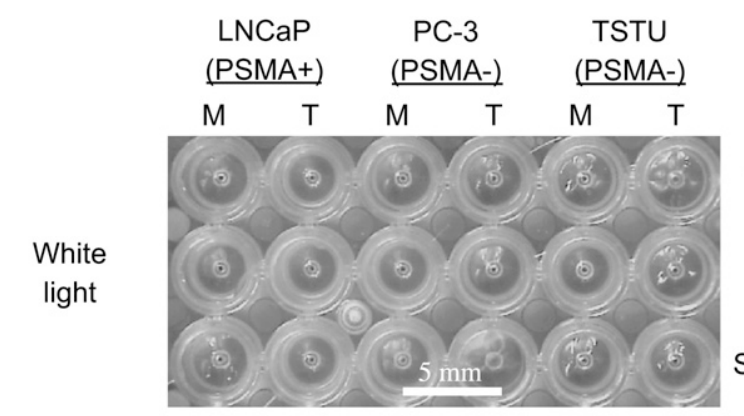

TBS

PBS

Serum

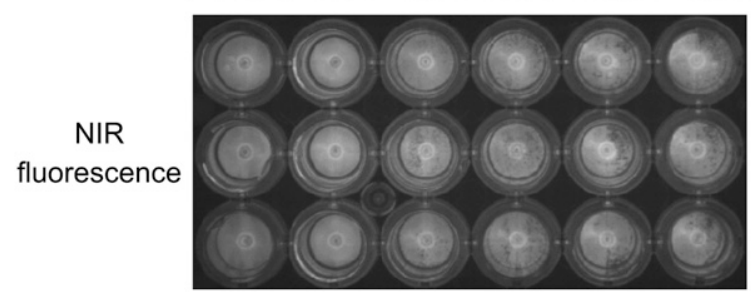

TBS

PBS

Serum

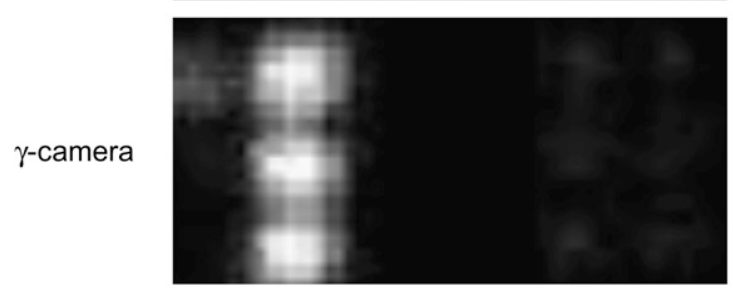

TBS

PBS

Serum

FIGURE 4. Radioscintigraphic imaging of ${ }^{99 \mathrm{~m} T \mathrm{~T}-\text {-labeled }}$ PSMA-specific radiotracers: Live cell binding of $99 \mathrm{mTC}-\mathrm{la}$ (GPI monomer; $M$ ) and 99mTc-IVa (AdamGPI trimer, T) was performed in TBS (top row), PBS (middle row), and 100\% serum (bottom row) for $20 \mathrm{~min}$ at $4^{\circ} \mathrm{C}$ using PSMA-positive LNCaP cells (left), PSMA-negative PC-3 cells (middle), and PSMA-negative TsuPR1 cells (right) grown on 96-well filter plates, followed by extensive washing. Cells were independently loaded with NIR fluorophore IR-786 to assess viability and confluence. Shown are white light (top), NIR fluorescence (middle), and $\gamma$-detector (bottom) images of cells grown on 96well filter plates.

perform all affinity measurements on living cells at $4{ }^{\circ} \mathrm{C}$. However, both NIR fluorescent GPI derivatives (2) and ${ }^{99 \mathrm{~m} T c-l a b e l e d ~ d e r i v a t i v e s ~(d a t a ~ n o t ~ s h o w n) ~ a r e ~ c o n c e n t r a t e d ~}$ inside cells via endocytosis, which serves to "amplify" radiotracer signal over time. This important feature of PSMA will likely improve in vivo performance and also needs to be incorporated into pharmacokinetic modeling.

\section{CONCLUSION}

Trimeric GPI conjugated to ${ }^{99 \mathrm{~m}} \mathrm{Tc}-\mathrm{MAS}_{3}$ (IVa) may someday be a valuable diagnostic agent for clinical use. It has a $3 \mathrm{nM}$ affinity for the surface of living prostate cancer cells in serum; 99\% of it is unchanged after incubation in warm serum for $4 \mathrm{~h}$; and covalent conjugation to ${ }^{99 \mathrm{~m}} \mathrm{Tc}-\mathrm{MAS}_{3}$ is performed in 1 step without the need for subsequent purification. Ongoing experiments will characterize its biodistribution and clearance in vivo.

\section{ACKNOWLEDGMENTS}

We thank Pavel Majer, Takashi Tsukamoto, and Barbara Slusher from MGI Pharma for supply of the GPI compound, Jürgen T. Renze for initial preparation of $\mathrm{MAS}_{3}$, J. Anthony Parker for many helpful discussions, Barbara L. Clough for editing, and Grisel Vazquez for administrative assistance. This work was supported by NIH grant R01-CA-115296, grant DFG MA 2529/3 from the Deutsche Forschungsgemeinschaft, and grants from the Lewis Family Fund and the Ellison Foundation.

\section{REFERENCES}

1. Jemal A, Murray T, Ward E, et al. Cancer statistics, 2005. CA Cancer J Clin. 2005;55:10-30.

2. Humblet V, Lapidus R, Williams LR, et al. High-affinity near-infrared fluorescent small-molecule contrast agents for in vivo imaging of prostatespecific membrane antigen. Mol Imaging. 2005;4:448-462.

3. Pomper MG, Musachio JL, Zhang J, et al. ${ }^{11} \mathrm{C}-\mathrm{MCG}$ : synthesis, uptake selectivity, and primate PET of a probe for glutamate carboxypeptidase II (NAALADase). Mol Imaging. 2002;1:96-101.

4. Tang H, Brown M, Ye Y, et al. Prostate targeting ligands based on N-acetylated alpha-linked acidic dipeptidase. Biochem Biophys Res Commun. 2003;307:8-14.

5. Israeli RS, Powell CT, Corr JG, Fair WR, Heston WD. Expression of the prostate-specific membrane antigen. Cancer Res. 1994;54:1807-1811.

6. Israeli RS, Powell CT, Fair WR, Heston WD. Molecular cloning of a complementary DNA encoding a prostate-specific membrane antigen. Cancer Res. 1993;53:227-230.

7. Humblet V, Misra P, Frangioni JV. An HPLC/mass spectrometry platform for the development of multimodality contrast agents and targeted therapeutics: prostate-specific membrane antigen small molecule derivatives. Contrast Media Mol Imaging. 2006;1:196-211.

8. Guhlke S, Schaffland A, Zamora PO, et al. ${ }^{188}$ Re- and ${ }^{99 m}$ Tc-MAG3 as prosthetic groups for labeling amines and peptides: approaches with pre- and postconjugate labeling. Nucl Med Biol. 1998;25:621-631.

9. Chang F, Qu T, Rusckowski M, Hnatowich DJ. NHS-MAS3: a bifunctional chelator alternative to NHS-MAG3. Appl Radiat Isot. 1999;50:723-732.

10. Nakayama A, Bianco AC, Zhang CY, Lowell BB, Frangioni JV. Quantitation of brown adipose tissue perfusion in transgenic mice using near-infrared fluorescence imaging. Mol Imaging. 2003;2:37-49.

11. De Grand AM, Frangioni JV. An operational near-infrared fluorescence imaging system prototype for large animal surgery. Technol Cancer Res Treat. 2003; 2:553-562.

12. Nakayama A, del Monte F, Hajjar RJ, Frangioni JV. Functional near-infrared fluorescence imaging for cardiac surgery and targeted gene therapy. Mol Imaging. 2002;1:365-377.

13. Mammen M, Choi SK, Whitesides GM. Polyvalent interactions in biological systems: implications for design and use of multivalent ligands and inhibitors. Angew Chem Int Ed. 1998;37:2754-2794.

14. Maison W, Frangioni JV, Pannier N. Synthesis of rigid multivalent scaffolds based on adamantane. Org Lett. 2004;6:4567-4569.

15. Rusckowski M, Qu T, Gupta S, Ley A, Hnatowich DJ. A comparison in monkeys of ${ }^{99 \mathrm{~m} T c}$ labeled to a peptide by 4 methods. J Nucl Med. 2001;42:1870-1877.

16. McDevitt MR, Barendswaard E, Ma D, et al. An alpha-particle emitting antibody ([213 Bi]J591) for radioimmunotherapy of prostate cancer. Cancer Res. 2000;60: 6095-6100.

17. Smith-Jones PM, Vallabahajosula S, Goldsmith SJ, et al. In vitro characterization of radiolabeled monoclonal antibodies specific for the extracellular domain of prostate-specific membrane antigen. Cancer Res. 2000;60:5237-5243.

18. Visser GW, Gerretsen M, Herscheid JD, Snow GB, van Dongen G. Labeling of monoclonal antibodies with rhenium-186 using the MAG3 chelate for radioimmunotherapy of cancer: a technical protocol. J Nucl Med. 1993;34:19531963.

19. Liu H, Rajasekaran AK, Moy P, et al. Constitutive and antibody-induced internalization of prostate-specific membrane antigen. Cancer Res. 1998;58: 4055-4060. 